\title{
O TRATAMENTO AOS MUTANTES COMO ALEGORIA DA PATOLOGIZAÇÃO DE SUJEITOS DE GÊNEROS NÃO-INTELIGÍVEIS: UMA LEITURA A PARTIR DAS HQ DOS X-MEN
}

\author{
TRATAMIENTO DE MUTANTES COMO UNA ALEGORÍA DE LA PATOLOGIZACIÓN \\ DE SUJETOS DE GÉNEROS NO INTELIGIBLES: UNA LECTURA DE LA HQ X-MEN
}

\author{
TREATMENT OF MUTANTS AS AN ALLEGORY OF THE PATHOLOGIZATION OF \\ SUBJECTS OF NON-INTELLIGIBLE GENDERS: A READING FROM THE X-MEN \\ $H Q$
}

\author{
Fábio Mahal da Silva GONÇALVES ${ }^{1}$ \\ Fábio Tadeu REINA ${ }^{2}$ \\ Ranyella Cristina de SIQUEIRA ${ }^{3}$ \\ Marco Aurélio de CARVALHO ${ }^{4}$
}

RESUMO: As personagens das histórias em quadrinhos têm ganhado notoriedade ao se transpor ao mundo do cinema e da TV, em especial os X-men. Com grande potencial de reproduzir percepções e concepções sobre os mais variados aspectos da vida humana, as HQ têm servido como pano de fundo para reflexões sobre questões socioculturais e morais. Tendo como fonte de pesquisa as edições de 1 a 6 do arco Superdotados da revista Os Surpreendentes $X$-men, relacionaremos a patologização dos mutantes da HQ como alegoria à patologização de minorias sexuais, oferecendo material para reflexão e trabalho pelo respeito à diversidade sexual. Entendendo a oferta de uma cura mutante como alegoria da cura gay, desvelaremos a alegoria subjacente na condição das personagens e sua luta contra a patologização da condição de mutante relacionando à mesma situação com os ditos gêneros não-inteligíveis.

PALAVRAS-CHAVE: Gênero não-inteligível. Educação sexual. Diversidade sexual.

RESÚMEN: Los personajes de las historietas han ganado notoriedade al trasponerse para el mundo del cine e de la televisión, en especial los X-men. Con gran potencial de reproducir percepciones y concepciones sobre los más distintos aspectos de la vida humana, las historietas han servido de puntapié para reflexiones sobre cuestiones socioculturales e morales. Teniendo como fuente de investigación la ediciones de 1 a 6 del arco Superdotados de la historieta Los

${ }^{1}$ Universidade Estadual Paulista (Unesp), Araraquara - SP - Brasil. Mestrando no Programa de Pós-graduação Profissional em Educação Sexual. FCL/Unesp-Araraquara. ORCID: http://orcid.org/0000-0002-5956-3735. Email: fabiomahal@gmail.com

${ }^{2}$ Universidade de Araraquara (Uniara), Araraquara - SP - Brasil. Doutor em Educação Escolar pela FCL/UnespAraraquara e professor titular do Centro Universitário de Araraquara (Uniara). ORCID: https://orcid.org/00000002-2591-2378. E-mail: ftreina@ hotmail.com.

${ }^{3}$ Universidade Estadual Paulista (Unesp), Araraquara - SP - Brasil. Mestre em Educação Sexual no Programa de Pós-graduação Profissional em Educação Sexual. ORCID: https://orcid.org/0000-0003-3432-5498. E-mail: ranysiqueira@gmail.com

${ }^{4}$ Universidade Estadual Paulista (Unesp), Araraquara - SP - Brasil. Mestrando no Programa de Pós-graduação Profissional em Educação Sexual. ORCID: https://orcid.org/0000-0003-3960-9836. E-mail: marco_carvalho@outlook.com.br 
increíbles hombres $X$, relacionaremos la patologización de los mutantes de la historieta como alegoria a la patologización de las minorías sexuales, ofreciendo material para reflexión y trabajo para el respecto a la diversidade sexual. Comprendiendo la oferta de la cura mutante como alegoría a la cura gay, desvelaremos la alegória subyacente en la condición de los personajes en su lucha contra la patologización de su condición de mutante relacionando a la situación de los sujetos de gêneros no-inteligibles.

PALABRAS CLAVE: Género no inteligible. Educación sexual. Diversidad sexual.

ABSTRACT: The characters of the comics have gained notoriety by transcending to the world of movies and television, especially the X-men. With great potential to reproduce perceptions and conceptions about the most different aspects of human life, the comics have served as a background for a reflection on social, cultural and moral issues. Having as a source of research the editions of 1 to 6 of the super gifted arc of the comics The incredible X-men, we will relate the pathology of the mutants of the comics as an allegory to the pathologization of sexual minorities, offering material for reflection and work for the respect to sexual diversity. Understanding the offer of the mutant cure as an allegory to the gay cure, we will reveal the underlying allegory in the condition of the characters in their fight against the pathologization of their mutant status, relating to the situation of the subjects of non-intelligible genders.

KEYWORDS: Non-intelligible gender. Sexual education. Sexual diversity.

\section{Introdução}

As revistas em quadrinhos, segundo Eisner (1989), constituem-se o principal veículo de arte sequencial e desde sua criação na virada do século 20, encontraram um público amplo, sendo, em particular, parte do repertório inicial literário da maioria das crianças e jovens. As primeiras histórias em quadrinhos surgiram por volta de 1934 e continham, geralmente, uma coleção de obras curtas.

Os modernos artistas dos quadrinhos vêm desenvolvendo em seus trabalhos a sobreposição entre palavra e imagem e, segundo Eisner (1989), conseguiram a hibridação bemsucedida entre prosa e imagem. Essa configuração geral das histórias em quadrinhos exige do leitor capacidades interpretativas visuais e verbais. Isso torna a leitura de histórias em quadrinhos uma atividade de percepção estética e esforço intelectual. De acordo com Eisner:

Em sua forma mais simples, os quadrinhos empregam uma série de imagens repetitivas e símbolos reconhecíveis. Quando são usados vezes e vezes para expressar ideias similares, tornam-se uma linguagem - uma forma literária, se quiserem. E é essa aplicação disciplinada que cria a "gramática" da Arte Sequencial (EISNER, 1989, p. 8). 
No entanto, essa tentativa de aproximar os quadrinhos da literatura é, por vezes, criticada. Zeni (2014) tentou fazer essa aproximação, por acreditar se tratar de um meio para o reconhecimento dos quadrinhos como arte autônoma e digna de valorização. Porém, o autor reconhece que, nessa tentativa, estava desvalorizando a arte que tanto pretendia valorizar. Quadrinhos não são literatura assim como dança, teatro e cinema também não o são. Ao que, chegou à conclusão:

Do ponto de vista literário, não apenas os quadrinhos, mas também o cinema, a dança e a pintura são mídias deficitárias, que não podem ser valorizadas tanto quanto um romance ou um poema. Porém, se invertemos a perspectiva e olharmos dos quadrinhos para a literatura, também percebemos que a prosa ou a poesia é incapaz e incompleta diante das histórias em quadrinhos, pois faltam as imagens, as onomatopeias visuais, os quadros, sarjeta (ZENI, 2014, p. 126).

Recorrendo ao conceito de Ramos (2010), os quadrinhos podem ser definidos como um hipergênero, um grande rótulo que agrega diferentes outros gêneros que têm em comum o uso da linguagem dos quadrinhos para compor um texto narrativo inserido em um contexto sociolinguístico interacional.

Segundo Margonari e Braga Jr. (2015), os quadrinhos constituem uma fonte eficaz de estímulo à leitura e ao desenvolvimento da competência leitora mostrando que o seu uso em sala de aula é extremamente eficaz. Alunos leitores de quadrinhos tendem a ter desempenho escolar melhor do que aqueles que não os leem, pois estas leituras são consumidas de forma lúdica e natural pelos estudantes, sem que, por vezes, isso seja imposto. Dizem os autores que:

São publicações que eles não esperam que estejam envolvidas em suas dinâmicas diárias de estudo, principalmente porque são produtos de entretenimento que contêm uma cultura, muitas vezes tachada historicamente como "cultura inútil" e, por isso mesmo, despertadora de interesse no alunado. Não há muito esforço ou convencimento na hora de pedir a leitura de uma HQ (ou congênere) (BRAGA JR.; MARGONARI, 2015, p. 1605).

A primeira história dos X-men foi lançada em 1963 na revista em quadrinhos Uncanny X-men ou, em português, Fabulosos X-men pela editora Marvel Comics. A história desse grupo de heróis gira em torno de sua luta para defender um mundo que os teme e os odeia, pelo simples fato de serem considerados uma ameaça por serem mutantes. Pessoas nascidas com poderes devido a mutações genéticas, mais especificamente graças ao denominado gene x. E assim se explica sua origem:

Todos os dias, nascem mutantes em números cada vez maior e o pânico e a paranoia da humanidade crescem exponencialmente. Os Mutantes são 
chamados de aberrações, monstruosidades genéticas. São humilhados, temidos, ofendidos, acusados de roubar trabalhos humanos, comer alimentos humanos e tomar cônjuges humanos. No entanto, eles continuam emergindo nas cidades, subúrbios, desertos e selvas. Precisam de professores, pessoas que os ajudem a superar a ira e os ensinem a usar suas estranhas habilidades de forma responsável. Sob nuvens de um crescente sentimento antimutante, o professor $\mathrm{X}$ criou um abrigo seguro em sua mansão em Winchester, para treinar jovens a usarem seus dons genéticos únicos para o aprimoramento de todos. Odiados e temidos pela humanidade, esses párias aventureiros continuam a aperfeiçoar seus estranhos poderes enquanto defendem o mundo dos mutantes que tiram vantagens de suas capacidades para subjugar a espécie humana (BEAZLEY; YOUNGQUIST; BRADY, 2005, p. 162).

Os poderes dos mutantes geralmente se manifestam na adolescência e muitos acabam expulsos de casa por suas famílias. Para poder lidar melhor com sua condição de mutante, o Professor X, o telepata mais poderoso do planeta, acolhe em seu lar jovens mutantes, oferecendo-lhes acolhimento e ensino, tanto acadêmico quanto emocional.

No universo dos X-men há alguns embates que os mutantes travam: um contra mutantes com desejo de subjugar os humanos e outro contra ameaças extraterrestres de dimensões paralelas e ameaçadoras à humanidade. No entanto, há um inimigo comum aos mutantes, a saber, humanos com o desejo de eliminar os mutantes, por considerá-los um amedrontamento à humanidade.

Sensíveis aos dramas vivenciados pelos mutantes e enxergando nisso uma alegoria da luta de minorias sociais da vida real, diversos pesquisadores têm tido interesse em enxergar tal condição de mutante como uma alegoria. Por alegoria podemos entender um discurso que "faz entender outro ou alude a outro, que fala de uma coisa referindo-se a outra, - uma linguagem que oculta outra, uma história que sugere outra" (MOISÉS, 2004, p. 14). A alegoria pode empregar palavras, figuras, pessoas, imagens e animais para compor e fazer compreender o outro a qual se refere, facilitando assim a compreensão de uma ideia.

Campos (2016) entende os X-men como uma alegoria da luta dos direitos humanos dos negros e afirma que o X-men conta a mais miscigenada história de heróis já vista até o momento. Os personagens Professor Xavier e Magneto teriam sido inspirados em Martin Luther King e Malcolm X, respectivamente. Braga Jr (2015) mostra que a criação dos X-men coincidiu com o discurso "I have a dream” de Martin Luther King em 1963 e há semelhanças entre o discurso de integração dos negros deste com o da integração mutante, e isso, segundo esse autor, se deve ao chamado "Método Marvel”.

A editora de quadrinhos Marvel Comics a partir da década de 1960, começou a implementar uma política de criação de personagens que privilegiava elementos do "social" coetâneo em suas produções. O "Método Marvel", 
como ficou conhecido, consistia em mesclar elementos de ficção e fantasia a partir dos temas sociais relevantes na opinião pública, sempre com um discurso mediador repleto de subterfúgios. A personalidade traumática, insegura e melodramática dos personagens, aliadas às reproduções de formações sociais coetâneas levariam as histórias a uma noção de realismo que, aliada ao crescente investimento na mudança de estrutura dos desenhos destes personagens, tornariam suas produções inovadoras, conquistando jovens leitores e aumentando as vendas (BRAGA JR, 2015, p. 132).

A cura mutante no universo das HQ dos X-men gerou discussões sobre como esses heróis podem ser analisados como uma alegoria de minorias. O longa " $X$-men - $O$ confronto final" (2006) despertou discussões a respeito da alegoria dos mutantes como figura de minorias da sociedade concreta, em especial os que também se tornaram alvos de patologização. Ilea (2009) relaciona a cura mutante do filme "X-men - O Confronto Final" (2006) com a questão da deficiência física. A autora argumenta que os argumentos pró e contra a cura mutante, assim como os desejos de alguns mutantes de se submeterem à cura, podem ser relacionados aos dos modelos médico-social acerca da deficiência física respectivamente. Ele diz que no

[...] modelo social, o problema não é físico. A sociedade cria a deficiência colocando rótulos, afirmando e limitando as opções para algumas pessoas. De acordo com essa premissa, a sociedade na qual vivem os deficientes/mutantes é culpada pelas dificuldades que eles enfrentam. [...] No modelo médico, a deficiência (ou o fato de ser mutante) é vista como uma condição indesejável e dolorosa que precisa ser consertada. A medicina e a ciência podem proporcionar curas e, assim, possibilitar que as pessoas deficientes e os mutantes desfrutem todas as liberdades que as pessoas "normais" têm (ILEA, 2009, p. 168).

Hopkins (2009) entende que a discussão sobre a cura de um modo mais amplo, referese àquilo que a sociedade julga como normal e anormal, ou seja, que ela legitima por meio de sua postura frente à questão. "Normal" aqui seria aquilo encarado como natural. O desejo pela cura, manifestado por alguns mutantes do universo Marvel, denota o fato de que serem seres sociais com forte desejo de pertencimento de um grupo e aceitação da sociedade em que estão inseridos, implicando a busca por características em comum e sua anulação enquanto mutante. A personagem Tempestade possui o poder de controlar o clima e isso não afeta sua aparência física, garantindo-lhe a possibilidade de se passar por "normal”. Dessa forma, é compreensível que Tempestade considere um absurdo e até covardia um mutante querer se curar para ser aceito na sociedade. Por outro lado, o mutante Fera, ao contrário de Tempestade, acha compreensível alguns mutantes buscarem a cura, pois entende que nem todos conseguem lidar com o fato de serem diferentes, aberrações aos olhos dos humanos. O próprio Fera possui uma mutação que torna seu corpo peludo e azul, com uma aparência bestial, embora suas habilidades como força, 
sentidos apurados e agilidade lhe sejam úteis, ele não consegue se passar por "normal". Isso nos alude ao exposto por Hopkins quando diz que esse

[...] conceito de "passar por" - fingir ser normal - é uma experiência de vida real, importante e bem documentada, vivida por alguns homossexuais e afroamericanos de pele clara. É uma experiência que dá ao anormal (o termo sendo usado apenas como descritivo) a habilidade de ser tratado como normal, permitindo-lhe confrontar ou não sua diferença e adaptação (HOPKINS, 2009, p. 24).

Na edição encadernada de Surpreendentes X-men: Superdotados lançada no Brasil, é revelada uma troca de e-mails, nos quais o roteirista Joss Wheadow diz em tom de brincadeira para o então editor-chefe da Marvel na época, se era realmente necessário falar da "maratona gay". Como dito anteriormente, o método Marvel implica na apropriação ampla do conceito de reprodução. Essa apropriação acontece em duas frentes: a de ordem mais abstrata, relacionando as situações histórico-sociais da vida contemporânea com forte apelo midiático e, circunscrevendo, na descrição das histórias, personagens e enredos; e a formal e imagética, relacionando a reprodução dos traços da realidade visual pelos desenhos (BRAGA JR, 2015). Se situarmos essa história com o momento histórico no qual foi lançada, notar-se-á que coincide com a aprovação do casamento gay, em 2004, no estado de Massachussets nos EUA, que se tornou o primeiro estado estadunidense a legalizar o matrimônio entre pessoas do mesmo sexo. Faz sentido que discussões acerca da homossexualidade tenham se tornado acaloradas na época e, então, tenham sido transportadas sob a forma de alegoria para as HQ's do X-men, especialmente no que diz respeito ao fato de considerar ou não considerar a homossexualidade como doença ou algo anormal.

Optou-se por se referir a todos aqueles que não estão dentro da norma heterossexual como gêneros não-inteligíveis, termo utilizado por Butler para os corpos que não se encontram na matriz heterossexual de inteligibilidade. Gênero, segundo Butler (2017), é um ato performativo que cria o masculino e feminino e gera a ilusão de "substância", de algo que sempre esteve ali. Butler entende que não há uma identidade de gênero por trás dos atos, e sim que a identidade é constituída através do ato. Nas próprias palavras de Butler (2017, p. 56), "não há uma identidade de gênero por trás das expressões de gênero; essa identidade é performativamente constituída, pelas próprias 'expressões' tidas como seus resultados".

Os gêneros inteligíveis, segundo Butler (2017, p. 43), "são aqueles que, em certo sentido, instituem e mantêm relações de coerência e continuidade entre sexo, gênero, prática sexual e desejo". A divisão binária do gênero em masculino e feminino é exigida e regulada 
pela instituição de uma heterossexualidade compulsória e naturalizada, e que justificaria a complementaridade desses.

Os gêneros ininteligíveis, ou seja, aqueles que rompem com a coerência e continuidade entre sexo, gênero, prática sexual e desejo, são considerados menos que humanos, vis e ininteligíveis. São aquilo que Butler (2017) define como:

O abjeto designa aquilo que foi expelido do corpo, descartado como excremento, tornado literalmente "Outro". Parece uma expulsão de elementos estranhos, mas é precisamente através dessa expulsão que o estranho se estabelece. A construção do "não eu" como abjeto estabelece as fronteiras do corpo, que são também os primeiros contornos do sujeito (BUTLER, 2017, p. 230).

Segundo Salih (2017), o objetivo de Butler ao teorizar sobre os gêneros inteligíveis e não-inteligíveis é rastrear os limites da inteligibilidade discursiva de modo a chamar a atenção como algumas identidades e corpos "pesam" e como outros não "pesam". O intuito é argumentar como as identidades de gênero inteligível são assumidas através da violenta rejeição e exclusão das identidades de gênero não-inteligíveis, ou seja, das que "não contam no contexto de uma matriz heterossexual, que tem interesse particular em manter sua própria estabilidade e coerência às custas de 'outras' identidades" (SALIH, 2017, p. 107). Gênero é um "estilo corporal", um ato (ou sequência de atos), uma "estratégia" para manter a estrutura social, já que aqueles que não "fazem” seu gênero corretamente são punidos pela sociedade.

Embora esse artigo tenha como foco a alegoria dos mutantes com os gêneros nãointeligíveis, vale ressaltar que o conceito de abjeto de Butler não se restringe apenas ao sexo e à heteronormatividade, mas a todos aqueles corpos cujas vidas não são consideradas vidas e cujas materialidades são vistas como "não importantes", como deficientes físicos e refugiados, por exemplo (PRINZ, MEIJER, 2002). Assim, mutantes podem ser considerados tão abjetos quantos aqueles grupos fora da ficção que sofrem rejeição.

\section{"Mutantes são pessoas doentes"}

Assim como se apresenta a possibilidade de cura para os mutantes dos quadrinhos da Marvel, o mesmo acontece na sociedade de fato. A possibilidade da denominada "cura gay", como ficou conhecida nos veículos de imprensa, alude a tentativas de mudar a orientação sexual de um sujeito homossexual. A Organização Mundial de Saúde, desde 1990, já não considera a homossexualidade como uma doença e o Conselho Federal de Psicologia do Brasil, em 1999, 
publicou a resolução $01 / 99^{5}$ que proíbe a oferta por psicólogos de tratamentos visando alterar a orientação sexual de homossexuais em conflito com sua sexualidade. No início de 2018, foi publicada a resolução 01/18 com regras semelhantes para o atendimento de pessoas transgêneros ${ }^{6}$. As duas resoluções têm em comum que psicólogos não devem fomentar preconceitos e nem a patologização de homossexuais e transgêneros. Tais normas têm sido alvos de processos judiciais e projetos de lei no congresso por parte de membros de grupos conservadores que defendem a liberação desse tipo de prática, mesmo sem comprovação científica de sua eficácia ${ }^{7}$.

Trata-se, portanto, de um tema ainda atual e que estimula as inquietações e indagações deste artigo e nos fez questionar: por que e para que curar os gêneros não-inteligíveis? O que faz com que determinadas instituições tenham a permissão de defender a cura? O que e quem define a fronteira entre sanidade ou transtorno, ou normalidade e a anormalidade?

Foucault, questiona a gênese dos regimes de verdade dos saberes e afirma que há relações de poder em todos os regimes de saber. Para Foucault (1979), o poder produz o saber, e a sua força se deve a produção de implicações positivas no campo do desejo e do saber. $\mathrm{O}$ poder cria o saber e a realidade de forma estratégica, ele é um exercício de relações que se concretizam como tecnologias num corpo (CARDOSO JR., 2006). A relação de poder para Foucault (1995) é uma ação sobre ações.

\begin{abstract}
Ele é um conjunto de ações sobre ações possíveis; ele opera sobre o campo de possibilidade onde se inscreve o comportamento dos sujeitos ativos; ele incita, induz, desvia, facilita ou torna mais difícil, amplia ou limita, torna mais ou menos provável; no limite, ele coage ou impede absolutamente, mas é sempre uma maneira de agir sobre um ou vários sujeitos ativos, e o quanto eles agem ou são suscetíveis de agir (FOUCAULT, 1995, p. 243).
\end{abstract}

Na compreensão de Dreyfus e Rabinow (1995), poder é um conjunto de relações abertas, as quais são coordenadas de formas irregulares, desiguais e móveis. O poder é multidirecional, ou seja, a essência do poder não está na dominação, tampouco restrita nos aparelhos de Estado, pois ela passa "pelas relações de poder existentes entre um homem e uma mulher, aquele que sabe e aquele que não sabe, entre os pais e as crianças” (FOUCAULT, 2005, p. 232). Analisemos a cena abaixo:

\footnotetext{
5 Disponível em: https://site.cfp.org.br/wp-content/uploads/1999/03/resolucao1999_1.pdf. Acesso em: 10 mar. 2020.

${ }^{6}$ Disponível em: http://site.cfp.org.br/wp-content/uploads/2018/01/resolucao_cfp_01_2018.pdf. Acesso em: 10 mar. 2020.

${ }^{7}$ Disponível em: http://politica.estadao.com.br/blogs/fausto-macedo/juiz-concede-liminar-que-permite-aplicacaode-cura-gay-por-psicologos/. Acesso em: 10 mar. 2020.
} 
Figura 1 - Os mutantes reagem quanto à ideia de que possa haver sua cura
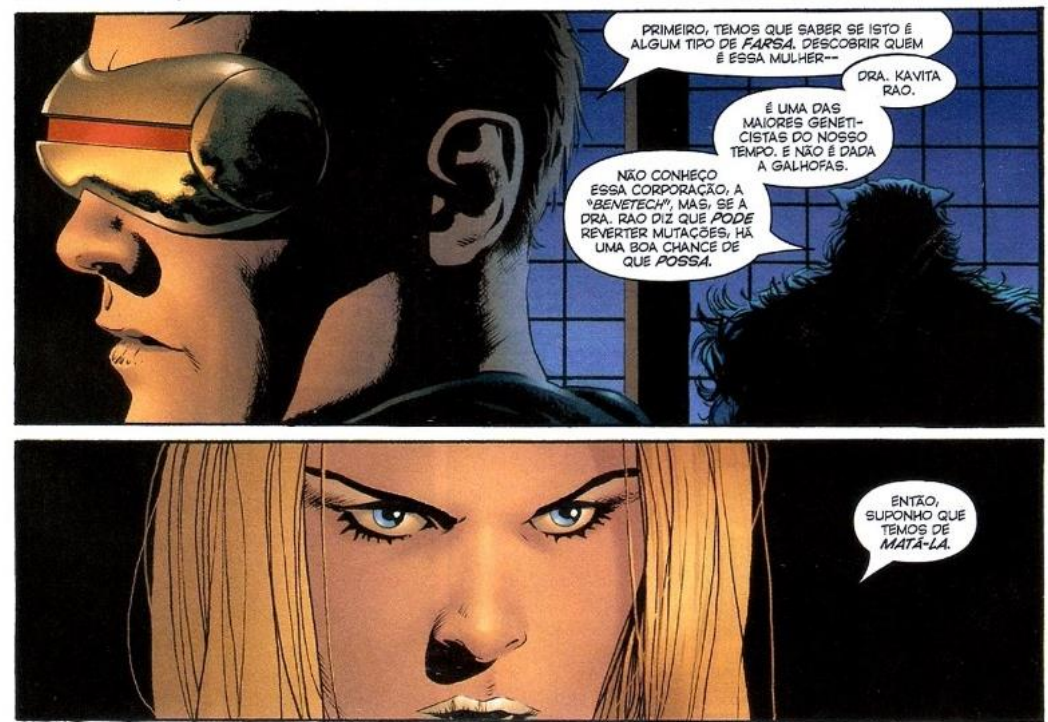

48

Fonte: Surpreendentes X-men (2008, p. 48).

Figura 2 - Mutantes conversam sobre as consequências da cura mutante na sociedade
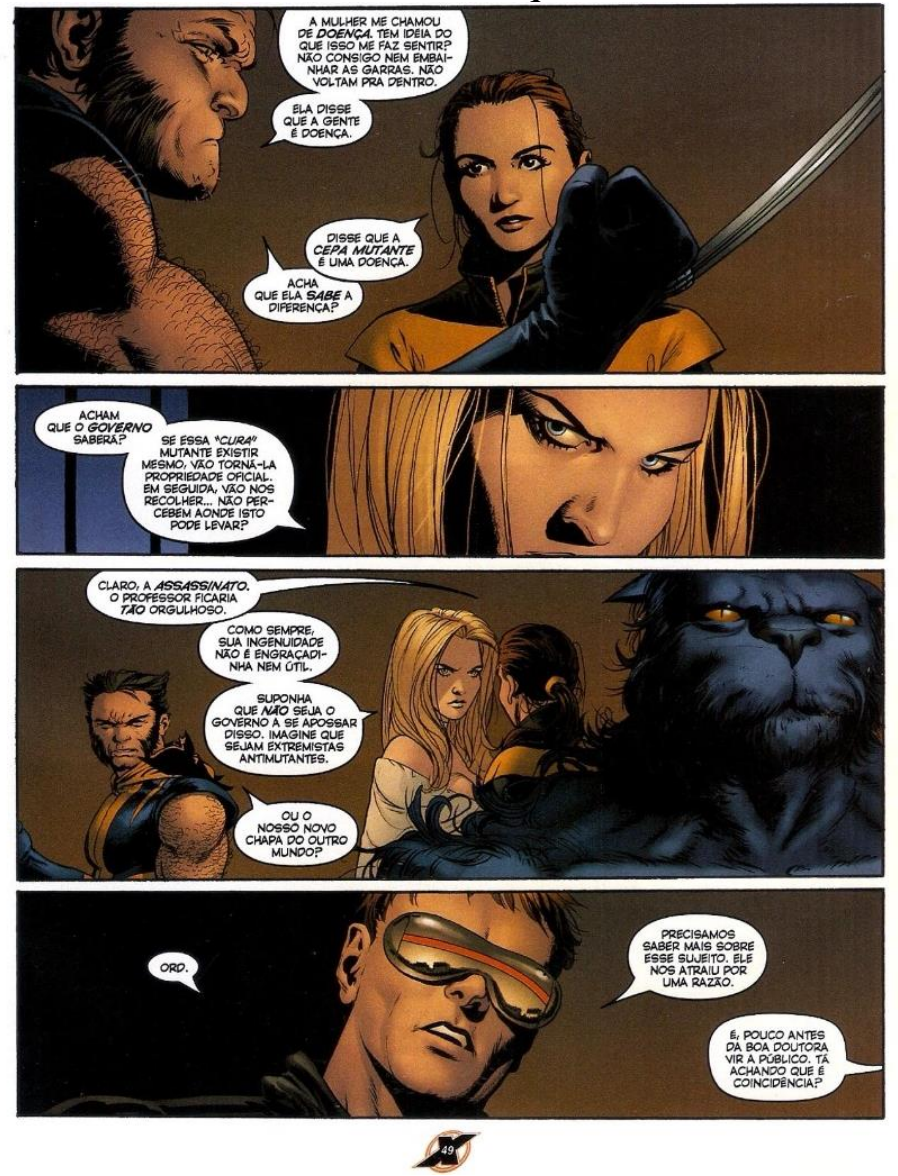

Fonte: Surpreendentes X-men (2008, p. 49). 
No diálogo apresentado acima, os mutantes estão discutindo sobre o plano de cura da Dra. Rao e suas possíveis consequências para eles em termos de direitos pessoais e políticos. Em suas falas, ficam expressas as relações cotidianas de poder presentes naquele contexto: da medicina, do alienígena Ord (referenciado como 'novo chapa do outro mundo') e dos extremistas antimutantes, que podem sustentar o funcionamento do Estado, o qual se torna preocupação secundária de Emma e Fera. Foucault (2005) afirma procurar na "vida cotidiana, nas relações entre os sexos, nas famílias, entre os doentes mentais e as pessoas sensatas, entre os doentes e os médicos” (p. 233) as relações de poder, pois esses são exemplos de lugares onde elas se inflamam constantemente. As relações de poder não possuem triunfo total e dominação reversível, uma vez que elas se entrelaçam, o poder recua, descola e investe em outros lugares e isso está envolto pelos seus métodos, suas tecnologias próprias, como visto na cena em análise (FOUCAULT, 1979).

A partir do século XVIII nasceu uma nova tecnologia do poder, a detenção normalizadora, apoiada numa vigilância densa e guiada pela disciplina, na qual a relação de crime e punição era dada de forma necessária e evidente. Em sua forma moderna, o poder se exerce no domínio da norma, e não da lei, constituindo a individualidade e natureza. Em outras palavras, as sociedades modernas não somente disciplinam, mas também normalizam, fazendo surgir um novo sistema de vigilância, de controle pela visibilidade e classificação, hierarquização, qualificação, colocação de limites e necessidade de diagnóstico. Nos quadrinhos abaixo, nota-se no discurso médico as relações de poder em definir, diagnosticar e normalizar quem são os mutantes. 
Figura 3 - A qualidade dos mutantes é comparada a uma doença e que pode ser curada

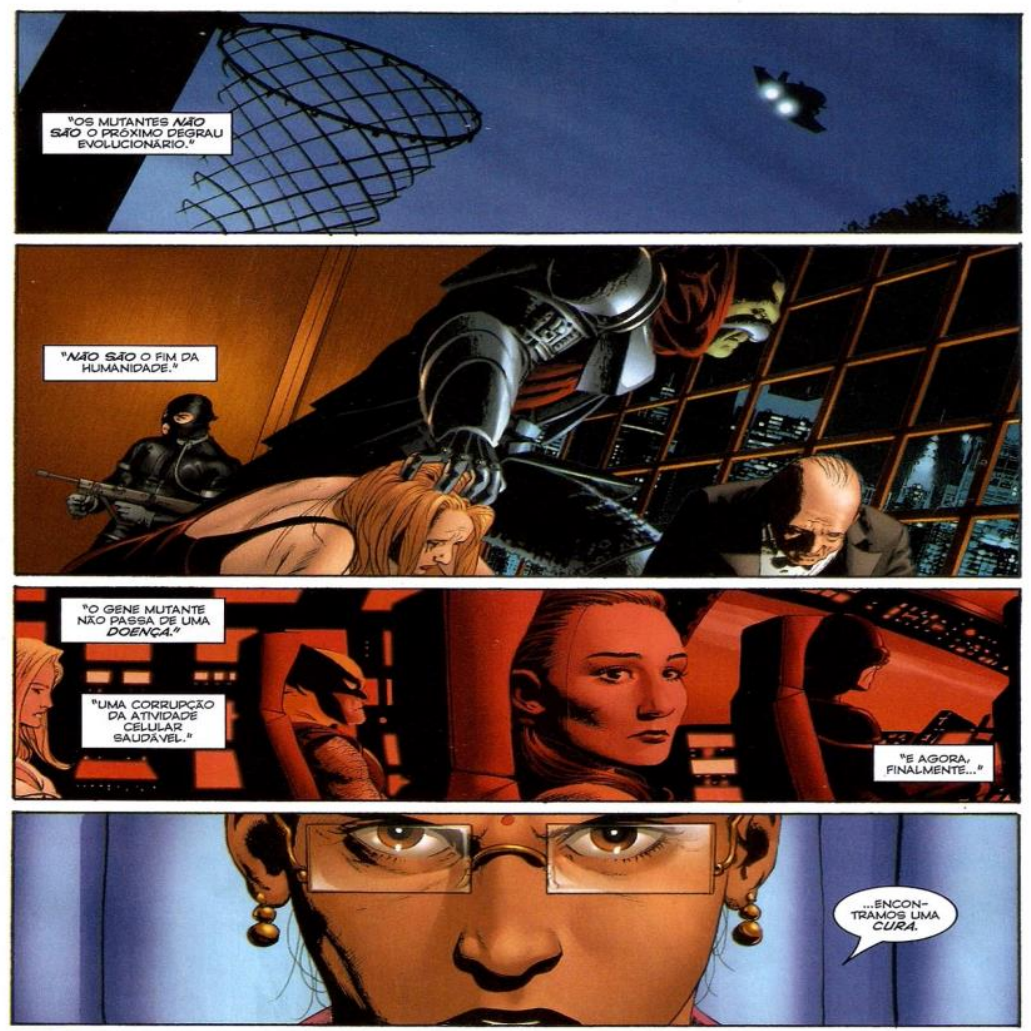

Fonte: Surpreendentes X-men (2008, p. 32).

Deste modo, a norma pode se converter em critério de divisão dos sujeitos. Este novo poder é pautado na constância, na disciplina e no anonimato, como o caso dos extremistas antimutantes e do alienígena, por exemplo. Qualquer sujeito pode ativá-lo sob a condição de estar na posição de fazê-lo e qualquer um pode estar sob seus mecanismos. Fera ao falar sobre a profissão da Dra. Rao, ilustra esse pensamento:

Figura 4 - Fera conversa com Doutora Rao sobre as ações dela enquanto propagadora da cura mutante.
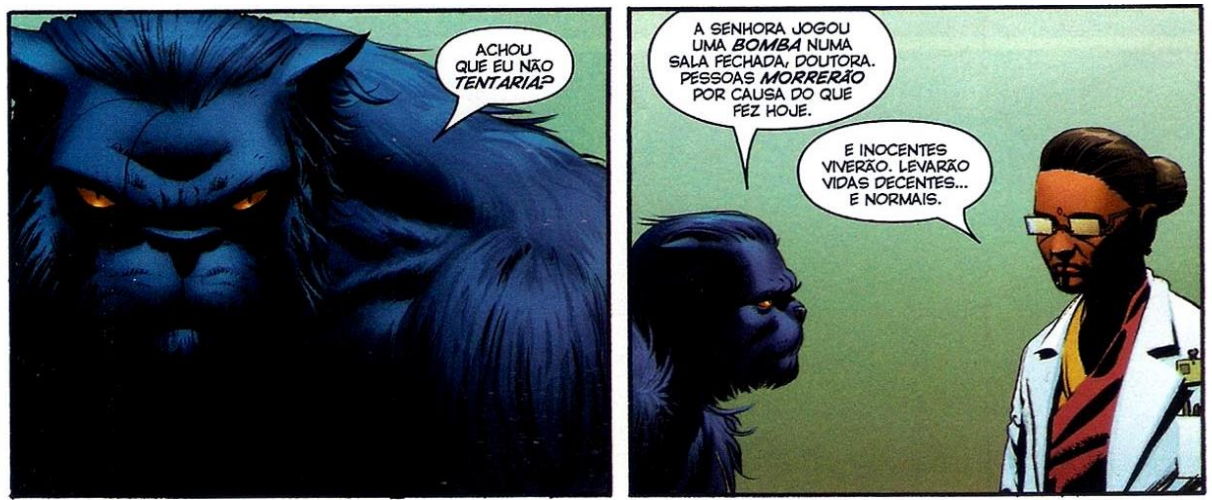

Fonte: Surpreendentes X-men (2008, p. 55). 
Figura 5 - Fera procura obter mais detalhes sobre a cura mutante.
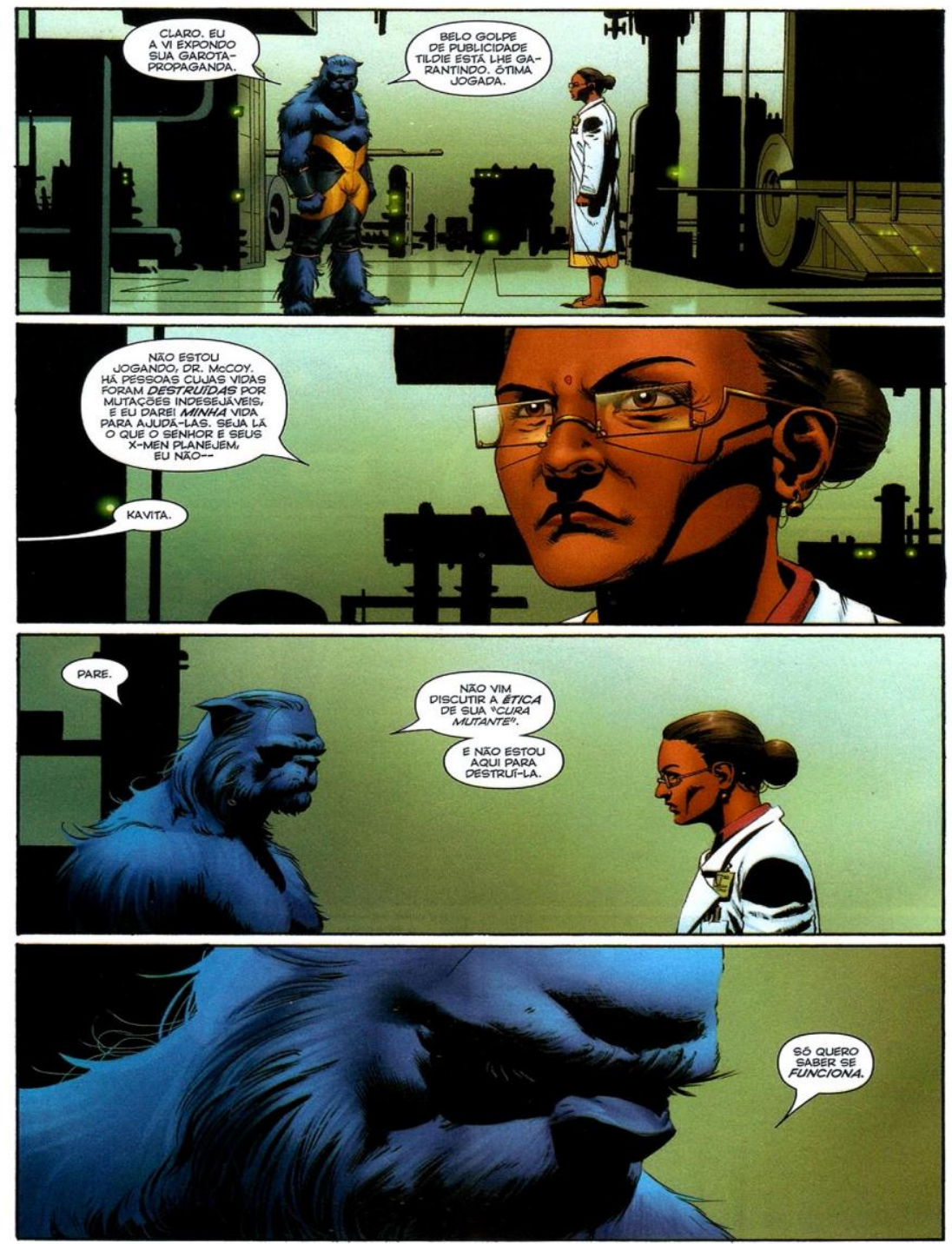

Fonte: Surpreendentes X-men (2008, p. 56).

Como afirma Dreyfus e Rabinow (1995, p. 214), as tecnologias de normalização "são uma parte integrante da criação, classificação e controle sistemático das anomalias no corpo social”. Deste modo, assim como as várias instituições e suas relações de poder se entrelaçam na adjetivação e diagnóstico de quem são os mutantes, observa-se o mesmo em nosso cotidiano no que diz respeito à cura da homossexualidade. As redes de poder de alguns profissionais da saúde e da educação, de figuras políticas e religiosas, da imprensa e do Estado em nosso país, atualmente, parecem buscar esforços na tentativa em definir e estabelecer um saber sobre a homossexualidade voltado a sua categorização enquanto transtorno ou doença que requer um tratamento ou cura. 
Na cena abaixo, o alienígena Ord invade o Instituto Xavier e, ao não encontrar os Xmen, decide atacar dois mutantes adolescentes, Asa e Armadura, que encontrou no lugar. Após golpear Armadura, Ord vai atrás de Asa, que tem o poder de voar e o apanha no ar. Ord injeta a cura mutante à força em Asa e deixa seu recado antes de o soltar em direção ao solo.

Figura 6 - Ord injeta a cura mutante em Asa e lhe diz que os mutantes não serão mais uma ameaça.
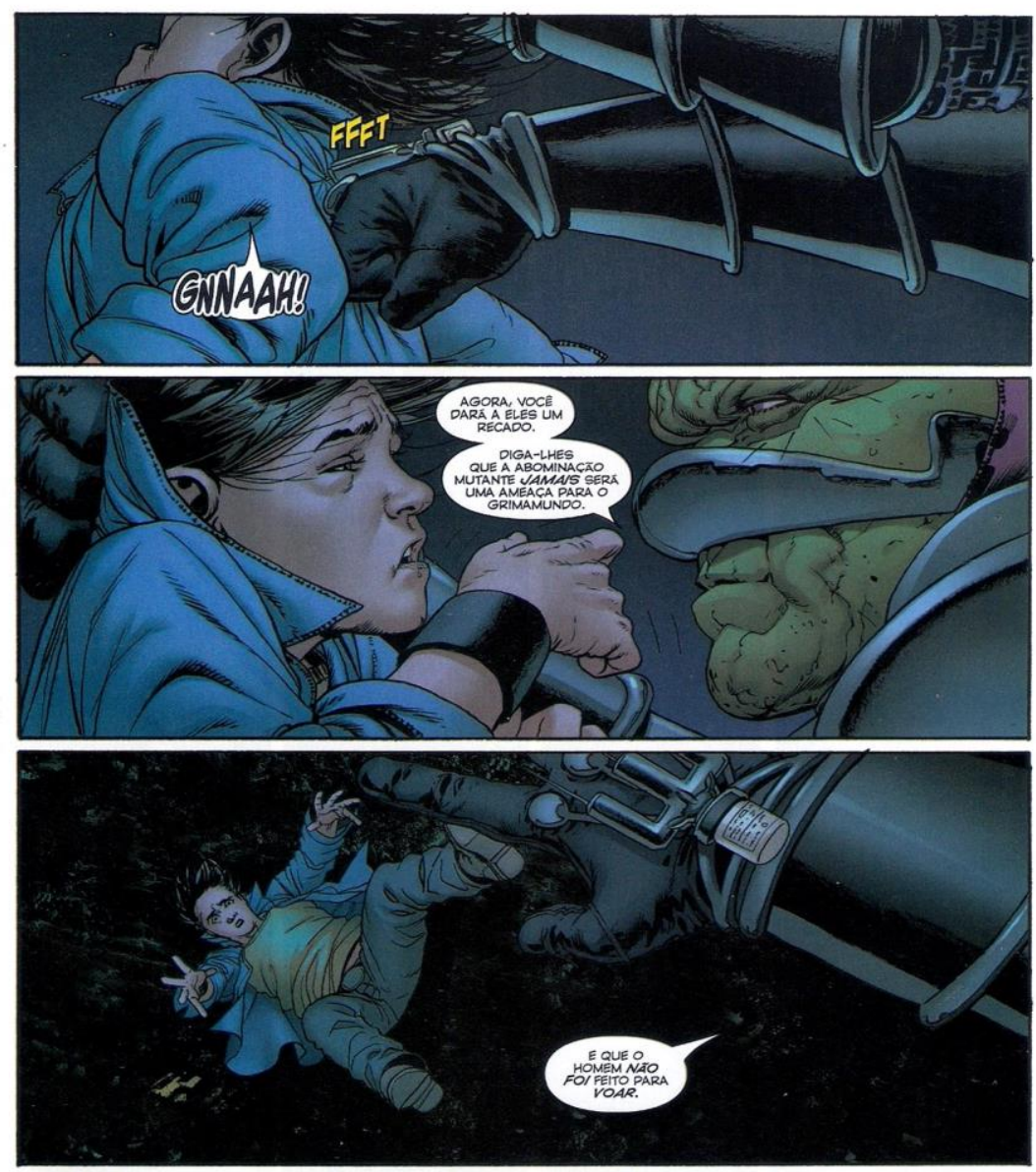

Fonte: Surpreendentes X-men (2008, p. 96).

$\mathrm{Na}$ frase "E que o homem não foi feito para voar", podemos pensar alegoricamente a relação de coerência e continuidade entre sexo, gênero, desejo e prática sexual que caracteriza o masculino e feminino em uma relação heterossexual, característico dos gêneros inteligíveis. No caso, a frase de Ord representa alegoricamente que homens não foram "feitos" para se relacionar sexualmente/afetivamente com outros homens. Em especial, a frase homofóbica repetida por fundamentalistas religiosos de que "Deus fez a mulher para o homem, e não o homem para o homem" (COENGA-OLIVEIRA, 2011) parece estar representada nessa senteça. O próprio uso da palavra "abominação" remete ao trecho de levítico 18:22 da bíblia referenciado por esses religiosos: "Não te deitarás com homem como com mulher; é 
abominação". "Voar" estaria relacionado ao ato de se deitar com alguém do mesmo sexo, ao mesmo tempo que soa como uma transgressão do que significa "ser humano". A imagem abaixo apresenta mais claramente o que os criadores dessa história estão falando alegoricamente através dos mutantes.

Figura 7 - Aproxima-se a noção de cura mutante à cura gay.
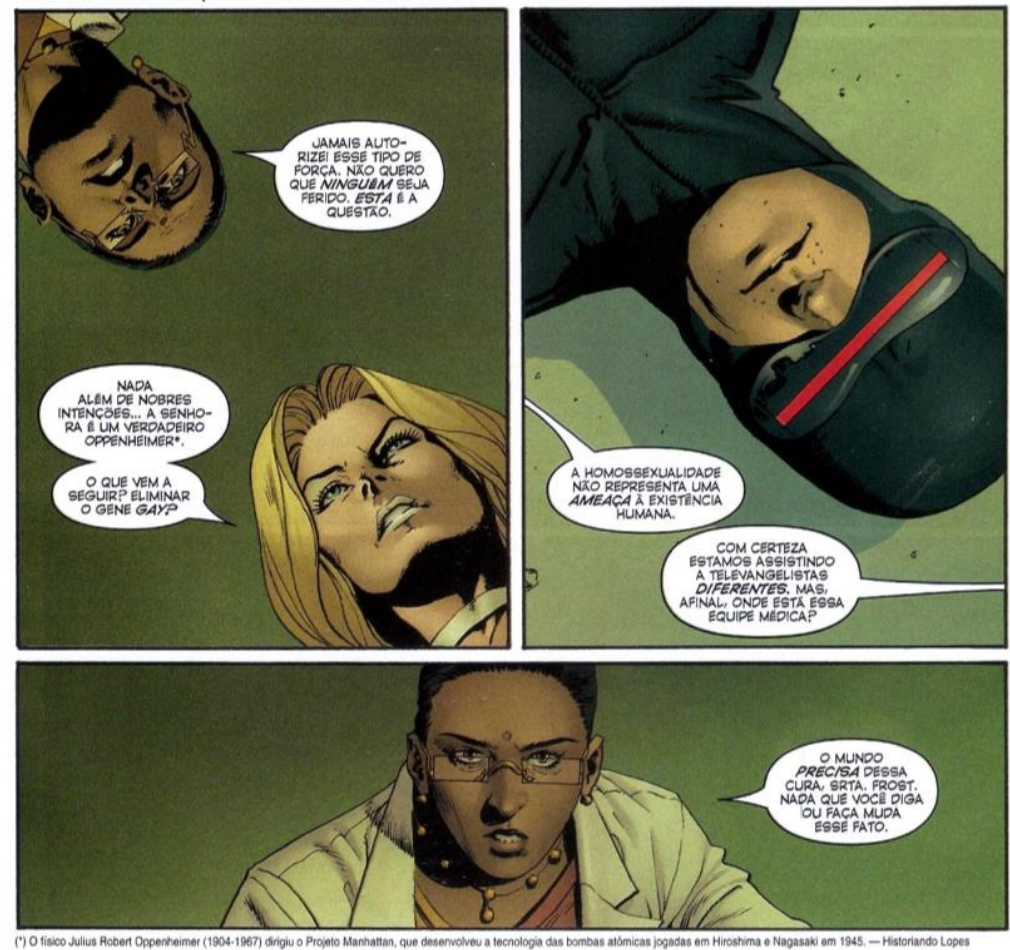

Fonte: Surpreendentes X-men (2008, p. 117).

Pode-se fazer aqui a associação entre o vilão Ord e aqueles que proferem discursos homofóbicos com base no discurso fundamentalista religioso. Segundo Machado e Prado (2012), a partir do século XIX, a regulação da sexualidade acontecia principalmente por meio da igreja, que punia comportamentos sexuais indesejados, considerados crime ou pecado. Tais atos chegaram a ser punidos até mesmo com pena capital nos anos da santa inquisição, no passado, e ainda hoje em alguns países onde o extremismo se faz presente. Por conseguinte, após a invenção da heterossexualidade e seu estabelecimento como natural e única experiência identitária saudável e correta, comportamentos não heterossexuais passaram de crime e pecado para doença. Os procedimentos punitivos de antes foram substituídos por outros, já que doenças devem ser tratadas. A ciência moderna teve papel fundamental nessa mudança de paradigma. Cientistas dessa época, em especial aqueles que se encontravam "na medicina, na fisiologia e na psicologia, foram cruciais na construção desse novo discurso, passando a ter um papel central 
na construção das concepções e normalizações que incidiram sobre as identidades sexuadas." (MACHADO; PRADO, 2012, p. 38)

A ciência moderna, fundamentada pela noção de verdade universal, produziu sofisticados discursos capazes de regular os papéis e comportamentos sexuais, ocultando seu comprometimento ideológico com os valores morais de uma classe dominante. Assim, estes discursos estavam autorizados a proferir suas crenças como se fossem verdades, uma vez que a noção de verdade na ciência moderna se autoriza a totalizar determinados aspectos da realidade, de modo que as experiências que se afastem ou neguem suas premissas são desqualificadas ou invalidadas (MACHADO; PRADO, 2012, p. 37-38)

Figura 8 - Mutantes expressam seu desejo na cura mutante e assim se tornarem humanos.
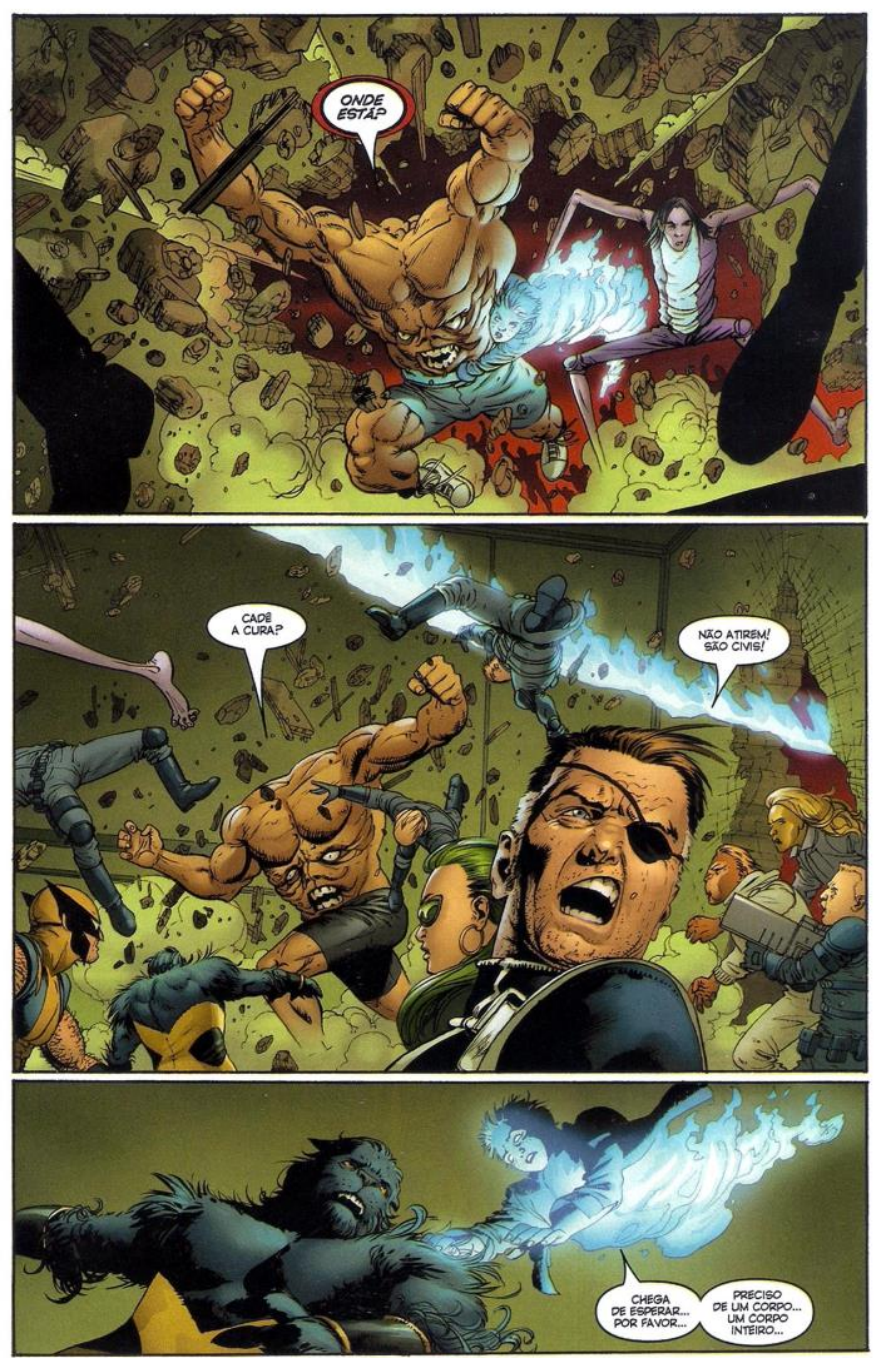

Fonte: Surpreendentes X-men (2008, p. 138). 
Figura 9 - Fera se comove ao ouvir de outro mutante a necessidade de ser humano.

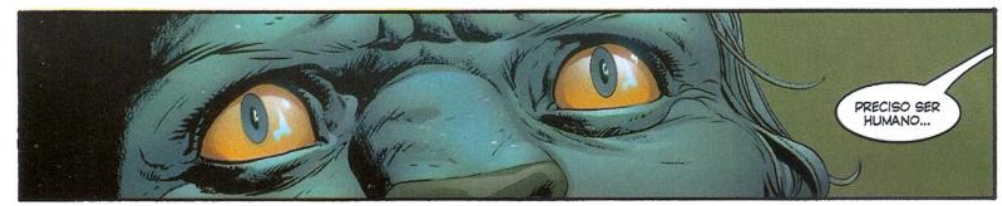

Fonte: Surpreendentes X-men (2008, p. 139).

Nessa cena, vemos a fala de um mutante que busca a cura. Um deles não tem cabeça e seu rosto se encontra na barriga, outro tem braços e pernas extremamente longas, e assim por diante. Analisemos a frase dita pelo mutante de forma gasosa azul sobre seu corpo e sobre a necessidade de ter um "corpo" inteiro para poder "ser humano". É aqui que recorremos às ideias de Butler (2017) sobre os corpos abjetos. Segundo Salih (2017), Butler rejeita a distinção a sexo/gênero e chega a dizer que sexo é gênero. Ao aceitar que o corpo não pode existir fora do discurso "generificado", deve-se "admitir também que não existe um corpo que não seja, já e desde sempre, 'generificado'. Isso não significa que não exista essa coisa que é o corpo material, mas que só podemos apreender essa materialidade através do discurso (SALIH, 2017, p. 105).”

A marca do gênero parece "qualificar" os corpos como corpos humanos. Por exemplo, o feto se humaniza quando a pergunta "menino ou menina" é respondida com base na genitália que aparece na tela do ultrassom. As imagens corporais que não se encaixam em nenhum desses gêneros ficam fora do que é reconhecido como "humano", e são expelidas para o domínio do desumanizado e do abjeto, que põe a fronteira na qual o próprio humano se estabelece. (BUTLER, 2017). O mutante de forma gasosa, tal como travestis, transexuais e intersexos, possui um corpo não qualificado como humano, por isso deseja possuir um corpo, uma vez que o atual campo de inteligibilidade não comporta a sua imagem corporal como inteligível.

Analisemos as imagens abaixo: 
Figura 10 - Fera divaga com Logan sobre sua essência
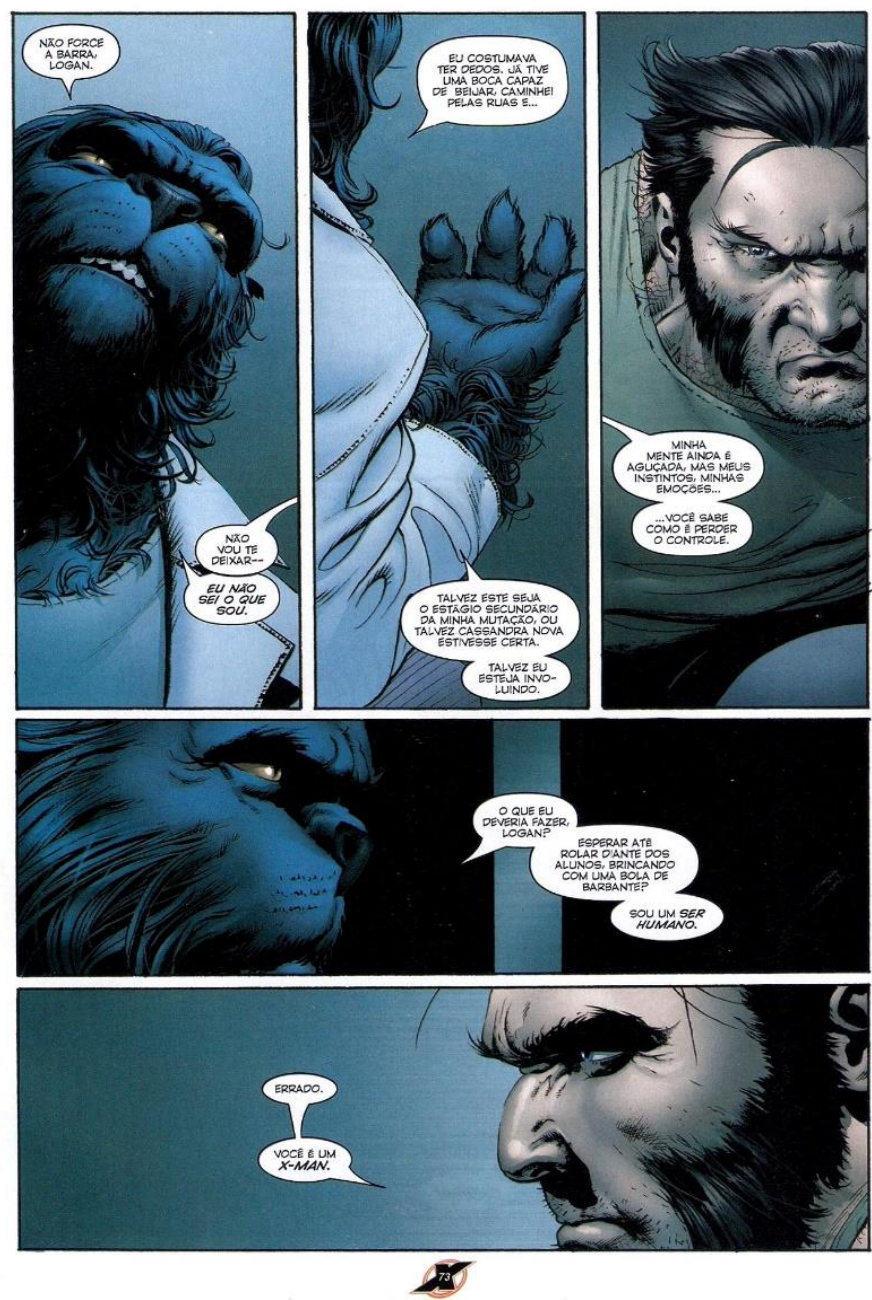

Fonte: Surpreendentes X-men (2008, p. 73).

Figura 11 - Logan fala sobre o perigo existente em mutantes desejarem a cura.

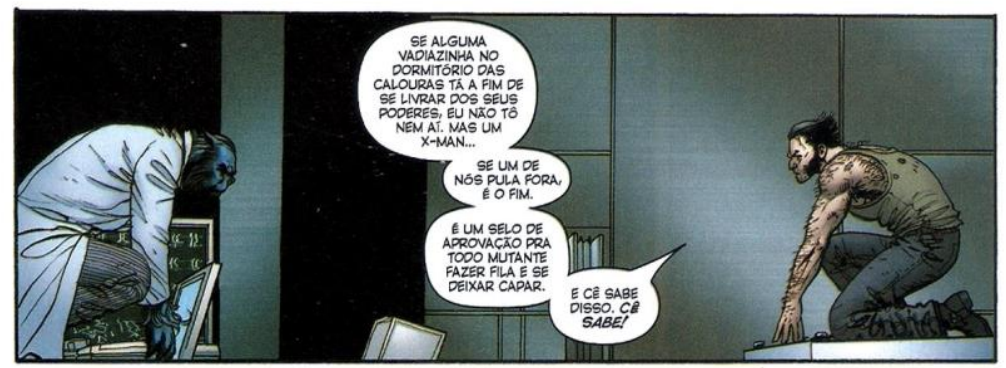

Fonte: Surpreendentes X-men (2008, p. 74).

Nessas cenas, pode-se observar que Fera, assim como o mutante de forma gasosa da imagem anterior, também se sente em conflito com sua aparência bestial azul. Por isso, sua expressão de conflito ao ouvir o mutante de forma gasosa dizer que precisa de um corpo inteiro para ser humano. 
O CID 10 tem como categoria diagnóstica a chamada orientação sexual egodistônica. Trata-se, segundo a Organização Mundial de Saúde (1993), de um transtorno no qual o indivíduo não tem dúvidas quanto às suas identidade e orientação sexual, mas que por conta de transtornos associados a elas, como ansiedade, depressão e outros, desejam por algum motivo alterá-las.

Segundo Prado e Machado (2012), indivíduos que são inferiorizados, interiorizam na construção de suas identidades, características sociais e psicológicas negativas atribuídas a eles, o que acaba por fortalecê-las ainda mais e legitimar os mecanismos e as formas de preconceito que os atingem. No caso da não-heterossexualidade, esse fenômeno é chamado de homofobia internalizada, que denota o quanto sofrimentos individuais podem ter sua origem nas estruturas sociais do preconceito. Segundo Porchat (2014, p. 16), é constante na fala de alguns homossexuais

[...] o sofrimento advindo da inadequação entre sua anatomia, seu gênero, seu desejo e sua prática sexual, inadequação esta que resulta de uma predominância da heterossexualidade - onde esses quatro itens aparentam uma concordância - dentro da visão de mundo manifesta na sociedade e, em grande parte, assimilada pelo próprio paciente (PORCHAT, 2014, p. 16).

Dessa forma, é possível compreender que tanto os mutantes dessa história quanto homossexuais e transexuais da vida real, em razão da angústia sentida devido ao preconceito social sofrido por eles, desenvolvem conflitos internos que os levam a buscar formas de alterar aquilo que os torna alvos de discriminação. E assim as estruturas de preconceito são fortalecidas.

O Conselho Federal de Psicologia, ao publicar a resolução 01/99, entende que o sofrimento de indivíduos não-heterossexuais não se deve à sua orientação sexual em si, mas a estrutura social que os oprime. Assim, a conduta de psicólogos diante de pacientes egodistônicos é orientada para o acolhimento desse sofrimento e não na oferta de uma terapia de "reversão sexual", ou "cura gay". Os X-men tem essa visão, entendendo que mutação em si não é a causa do sofrimento, mas a falta de acolhimento da sociedade para com os mutantes de modo a aceitá-los e ensiná-los a lidar com suas habilidades.

$\mathrm{Na}$ imagem abaixo, a agente Brand responsável por uma agência governamental que lida com extraterrestres revela aos X-men o motivo de Ord odiar mutantes e ter tentado eliminálos por meio da cura. Ord considera os mutantes uma ameaça ao seu planeta, o Grimamundo,

${ }^{8}$ Disponível em: https://site.cfp.org.br/cfp-vai-recorrer-da-sentenca-sobre-resolucao-01-99/. Acesso em: 10 mar. 2020. 
devido a uma profecia que diz que um mutante, provavelmente um X-men, estaria destinado a destruir sua terra natal.

Figura 12 - Conversa-se sobre uma suposta ameaça mutante
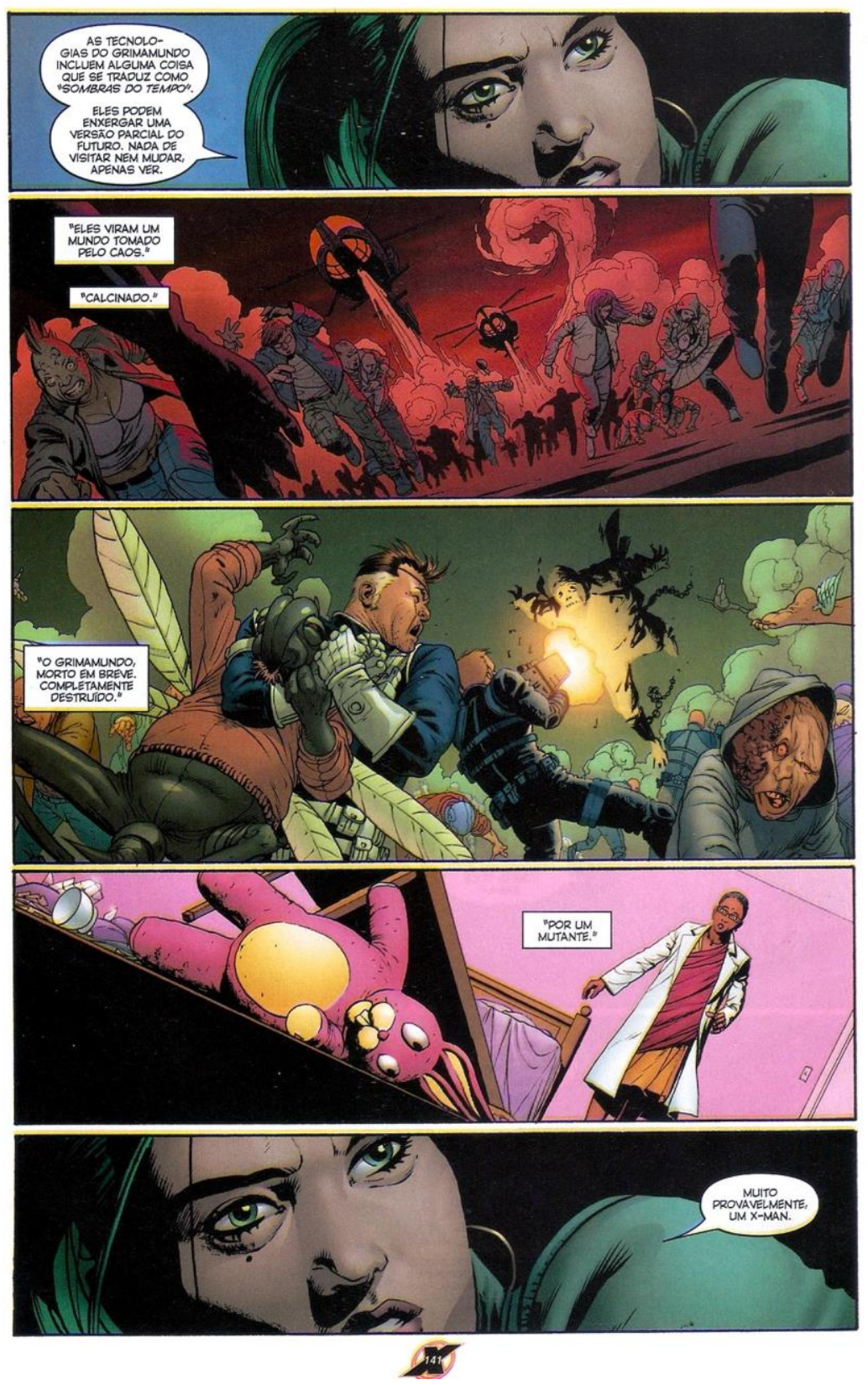

Fonte: Surpreendentes X-men (2008, p. 141).

Aqui podemos observar as relações de poder que permeiam o sentimento antimutante de Ord e sua analogia com a opressão que atinge os gêneros não-inteligíveis na vida real. A luta de Ord em curar/destruir os mutantes está relacionada com a crença no perigo que esses representam para a sobrevivência de seu mundo, que também pode ser interpretada como uma tentativa de manter a ordem social. Nesse sentido, podemos ver, alegoricamente, como os 
gêneros inteligíveis e não-inteligíveis, enquanto categorias políticas assim como os jogos de poder e sua manutenção, são representados nessa história:

Limitar as "identidades de gêneros" a apenas duas ou, ao menos, aos "gêneros inteligíveis" seria uma forma de manter o cenário social. A definição de gênero guarda relações com o poder. Gênero é um efeito de uma prática discursiva que, por sua vez, é efeito de uma prática reguladora que possui um determinado objetivo. O que a hegemonia heterossexual pretenderia garantir? A reprodução da espécie? A reprodução do poder patriarcal? (PORCHAT, 2014, p. 82).

O governo teria impasses éticos e legais se houvesse a tentativa de eliminar os mutantes por meio de genocídio, então a solução diplomática adotada foi patologizar os mutantes e assim "curá-los" e controlá-los, eliminando essa ameaça ao Grimamundo. Essa mesma situação ocorreu em relação aos gêneros não-inteligíveis.

Na HQ em questão, há um confronto com Ord e a pesquisa da cura é destruída e o assunto supostamente foi encerrado, até o momento, nas revistas que se seguiram, deixando a dúvida se a cura de fato era definitiva ou que apenas suprimia o poder mutante. No longa " $X$ men: o confronto final", que se baseou nessa mesma história, na cena final fica implícito que a cura talvez não fosse definitiva e, sim, que apenas suprimia temporariamente a mutação.

\section{Considerações finais}

As discussões acerca da cura mutante que buscamos relacionar como uma alegoria da cura gay apontam para a seguinte pergunta: o que precisa ser curado? O mutante de sua mutação ou a sociedade de seu preconceito contra mutantes? Parece ser uma questão semelhante acerca da deficiência física no modelo médico x modelo social, levantada por Ilea (2009) em sua análise do filme $X$-men: $O$ confronto final. São os chamados gêneros não-inteligíveis, representados alegoricamente pelos mutantes, que precisam se adaptar a um ideal de gênero inteligível ou é a sociedade que precisa rever a busca pela aparente coerência entre sexo, gênero, desejo e prática sexual às custas da criação de exclusão e violência contra determinados corpos?

Na HQ, a Dra. Rao, cientista que defende a cura mutante, embora declare ter boas intenções, mostra como o discurso científico pode estar alinhado com posições ideológicas de classes dominantes. No caso, as ações fortaleciam as próprias estruturas sociais que causavam o sentimento de inadequação e sofrimento dos seres com sua mutação e corpo. Isso também fica evidente no fato de nos bastidores, Ord estar envolvido com a cura e ter especial interesse em neutralizar, em suas palavras, a “abominação mutante”, que considera uma ameaça ao seu 
mundo. Na vida real, com os gêneros não-inteligíveis, essa mesma situação se repete: um discurso de boas intenções sobre "ajudar" pessoas em conflito com sua sexualidade a se curarem, mas que esconde um posicionamento ideológico alinhado com um ideal de gênero inteligível.

Esse artigo teve como intuito explorar a alegoria da patologização dos mutantes com a patologização das minorias sexuais da vida real, de modo a oferecer subsídios para educadores trabalharem tal temática no ambiente escolar, por meio de um gênero de fácil acesso e amplo gosto do público infantil e adolescente. Os quadrinhos, assim como os super-heróis, já fazem parte do cotidiano de jovens e adultos e, na maioria das vezes, são consumidos sem imposição à esses. No que diz respeito aos X-men, uma discussão por meio da alegoria desses com os gêneros não-inteligíveis pode reduzir a resistência para uma reflexão profunda do tema do preconceito e discriminação e promover o respeito à diferença, princípio básico da Educação brasileira. Há muito a se aprender com a alegoria dos mutantes e assim refletir sobre o que, afinal de contas, significa ser "humano".

\section{REFERÊNCIAS}

BEAZLEY, M.; YOUNGQUIST, J.; BRADY, M. Enciclopédia Marvel. São Paulo: Panini Comics, 2005.

BENTO, B. Na escola se aprende que a diferença faz a diferença. Rev. Estud. Fem., Florianópolis, v. 19, n. 2, ago. 2011.

BRAGA JR, A. X. Por uma sociologia da imagem desenhada: reprodução, estereótipo e actância nos quadrinhos de super-heróis da Marvel Comics. Orientador: Josimar Jorge Ventura de Morais. 2015. 333 f. Tese (Doutorado em Sociologia) - Universidade Federal de Pernambuco, Recife, 2015. Disponível em:

https://repositorio.ufpe.br/handle/123456789/16364. Acesso em: 10 mar. 2020.

BUTLER, J. Problemas de gênero. Feminismo e subversão da identidade. 14. ed. Rio de Janeiro, Civilização Brasileira, 2017.

CAMPOS, J. X-men e a alegoria da luta dos direitos humanos dos negros e a "heroicidade" de Martin Luther King e Malcolm X. Revista Eletrônica da FEATI, v. 1, n. 12, p. 190-194, jan./jul. 2016.

CARDOSO JR, H. R. Foucault em voo rasante. In: CARVALHO, A. B. de; LIMA DA SILVA, W. C. (Orgs.). Sociologia e Educação: leituras e interpretações. São Paulo: Avercamp, 2006. 
CEARÁ, A. T.; DALGALARRONDO, P. Transtornos mentais, qualidade de vida e identidade em homossexuais na maturidade e velhice. Rev. psiquiatr. clín., São Paulo: v. 37, n. 3, p. 118-123, 2010.

COENGA-OLIVEIRA, D. 'Se fosse normal, Deus teria criado Adão e Ivo!': a homofobia e a produção e regulação do sexo/gênero. Orientadora: Angela Maria de Oliveira Almeida. 2011. 140 f. Dissertação (Mestrado) - Universidade de Brasília, Programa de Pós-graduação em Psicologia Social, do Trabalho e das Organizações, 2011. Disponível em: https://repositorio.unb.br/handle/10482/9862. Acesso em: 10 mar. 2020.

DREYFUS, H.; RABINO, P. Em direção a uma teoria da prática discursiva. In: DREYFUS, H.; RABINOW, P. Michel Foucault: uma trajetória filosófica. Rio de Janeiro: Forense Universitária, 1995.

EISNER, W. Quadrinhos e arte sequencial. São Paulo: Martins Fontes; 1989.

FOUCAULT, M. Microfísica do poder. Rio de Janeiro: Graal, 1979.

FOUCAULT, M. História da sexualidade I: A vontade de saber. Rio de Janeiro: Edições Graal, 1985.

FOUCAULT, M. O sujeito e o poder. In: DREYFUS, H. L.; RABINOW, P. Michel Foucault: uma trajetória filosófica. Rio de Janeiro: Forense Universitária, 1995.

FOUCAULT, M. Em defesa da sociedade: curso no Collège de France (1975-1976). (Trad. Maria Ermantina Galvão). São Paulo: Martins Fontes, 1999.

FOUCAULT, M. Poder e saber. In: MOTTA, M. B. (Org.) Estratégia, poder-saber. 2. ed. Rio de Janeiro: Forense Universitária, 2005.

FOUCAULT, M. A arqueologia do saber. (Trad. Luiz Felipe Baeta Neves). Rio de Janeiro: Forense Universitária, 2008.

HOPKINS, P. D. A Sedução do Normal: Quem não quer ser mutante? In: Irwin, W. (Org.). X-men e a filosofia: visão surpreendente e argumento fabuloso no X-universo mutante. (Trad. Marcos Malvezzi). São Paulo: Madras, 2009.

ILEA, R. A cura mutante ou mudança social: Debatendo a deficiência. In: Irwin, W. (Org.). X-men e a filosofia: visão surpreendente e argumento fabuloso no X-universo mutante. (Trad. Marcos Malvezzi). São Paulo: Madras, 2009.

MARGONARI, D. M.; BRAGA JR, A. X. O humor das tiras em quadrinhos na educação para a diversidade sexual. Revista Ibero-americana de Estudos em Educação, v. 10, p. 1603$1621,2015$.

MOISÉS, M. Dicionário de termos literários. 12. ed. São Paulo: Cultrix, 2004.

ORGANIZAÇÃO MUNDIAL DE SAÚDE. Classificação de transtornos mentais e de comportamento da CID-10: descrições clínicas e diretrizes diagnosticas. Porto Alegre: Artmed, 1993. 
PORCHAT, P. Psicanálise e Transexualismo: Desconstruindo gêneros e patologias com Judith Butler. Curitiba: Juruá, 2014.

PRADO, M. A. M.; MACHADO, F. V. Preconceito Contra Homossexualidades: A

Hierarquia da Invisibilidade. 2. ed. São Paulo: Cortez, 2012.

PRINS, B.; MEIJER, I. C. Como os corpos se tornam matéria: entrevista com Judith Butler.

Rev. Estud. Fem., Florianópolis, v. 10, n. 1, p. 155-167, jan. 2002.

RAMOS, P. A leitura dos quadrinhos. São Paulo: Contexto, 2010.

SALIH, S. Judith Butler e a teoria queer. São Paulo: Editora Autêntica, 2017.

ZENI, L. Por que usar quadrinhos em sala de aula? Nona Arte: Revista Brasileira de Pesquisas em Histórias em Quadrinhos, v. 3, p. 125-129, 2014.

WHEDOW, J.; CASSADAY, J. Surpreendentes. X-Men Volume 1 - Superdotados. Panini Comics, 2008.

\section{Como referenciar este artigo}

GONÇALVES, Fábio Mahal da Silva; REINA, Fábio Tadeu; SIQUEIRA, Ranyella Cristina de; CARVALHO; Marco Aurélio. O tratamento aos mutantes como alegoria da patologização de sujeitos de gêneros não-inteligíveis: uma leitura a partir das HQ dos X-Men. Revista on line de Política e Gestão Educacional, Araraquara, v. 24, n. 1, p. 224-246, jan./abr., 2020. E-ISSN:1519-9029. DOI: https://doi.org/10.22633/rpge.v24i1.13058

Submetido em: 30/07/2019

Revisões requeridas: 20/10/2019

Aprovado em: 10/12/2019

Publicado em: 06/01/2020 